\title{
Income Poverty in Selected Countries of the European Union
}

\author{
Nad’a Birčiaková \\ Department of Marketing and Trade \\ Mendel University in Brno \\ Czech Republic \\ nada.birciakova@mendelu.cz
}

\author{
Jana Stávková \\ Department of Marketing and Trade \\ Mendel University in Brno \\ Czech Republic \\ jana.stavkova@mendelu.cz
}

\author{
Veronika Antošová \\ Department of Marketing and Trade \\ Mendel University in Brno \\ Czech Republic \\ veronika.antosova@mendelu.cz
}

\begin{abstract}
The presented article focuses on the assessment of the state of poverty in selected countries of the European Union on the basis of methodologies of European Union Statistics on Income and Living Conditions (EU SILC). Selected states are the representatives of areas of cultural affinity -specifically, the Czech Republic, Finland, France, Spain and the United Kingdom. The reference is between years 2005 and 2011. The basic variable is the monthly disposable income of an equivalised member. For the methodology, it is important that the basic unit is the household. The poverty threshold is defined as $60 \%$ of median equivalised income. Poverty is monitored also due to the economic activity of the population, which heavily relies on the head of household. In addition to poverty, it is essential to determine which populations are at risk of poverty. For this purpose, the Poverty Risk Index is used. Furthermore, it is essential to analyze the depth of poverty. It is also genuinely assumed that poverty is closely related to income inequality. This article makes use of simple regression analysis.
\end{abstract}

Keywords-poverty; EU-SILC; income and living conditions; death of poverty; poverty line

\section{INTRODUCTION}

Poverty exists in many countries around the world, and has done so for a very long time. To understand the danger, it is necessary to understand its dimensions and the process through which it deepens [1]. Townsend explains poverty as the inability to participate in society [2]. It should be emphasized that this inability is caused by lack of resources. Definitions of poverty vary, depending on who defines this concept. The general picture is provided by the World Bank, which defines poverty as a complex problem that involves a large number of phenomena, such as the inability to satisfy basic needs, lack of access to essential natural resources, lack of education and skills, poor health, malnutrition, poor quality housing and inadequate sanitation, violence and crime, lack of political freedom and opportunities to get ahead in society [3]. Poverty can be viewed from two main perspectives - as absolute poverty and relative poverty. Absolute (or extreme) poverty is a condition where people do not have the need or resources for life / survival. In such situations, they do not have enough water, food, medical care, shelter, etc. Relative poverty is a condition where an individual's income and his way of life are worse than the standard in a given country or region and prevent him from participating in economic, social or cultural activities. Relative poverty differs in different countries, depending on the standard of living found there [4].
For a long time scientists have tried to put into practice the concept of poverty in empirical research. The approaches are defined as:

- Measurement of income and expenditure and comparison with the budget,

- Measurement of income and expenditure and processing relative lack of income poverty,

- Determination of relative shortage of things or actions that are necessary,

- Interviewing people on the perception of poverty or disadvantage,

- Links to the concept of social exclusion [5].

Caminada suggest that poverty is a serious problem, even in highly developed welfare states [6]. Although countries spend a large part of their income on social security, poverty still persists. According to an international analysis of poverty, on average, about every tenth household in OECD countries lives in poverty.

Poverty is therefore not only a feature of developing countries. For this reason, the authors decided to ascertain the state of poverty in selected countries of the European Union, as it developed over the period between 2005 and 2011 and which groups are most at risk of poverty, which is particularly important for the development of measures in the field of social policy.

\section{METHODOLOGY}

In the present publication, living conditions and income situations in five countries of the European Union are compared, and the countries were selected on the basis of cultural affinity zones defined by Světlík [7].A representative was designated for each zone as follows:

- $\quad$ Finland (FI) for Sweden, Norway, Denmark, Finland,

- France (FR) for Austria, Switzerland and France,

- Spain (ES) for Italy, Spain, Greece and Portugal,

- United Kingdom (UK) for the United Kingdom and Ireland,

- Czech Republic (CZ), which was selected separately from those zones. 
The primary source of data is the results of an investigation called the European Union Statistics on Income and Living Conditions (EU-SILC). Results of EU-SILC contain objective and subjective aspects of income, poverty, social exclusion and other living conditions. Statistical EU-SILC investigations are compulsory for all EU countries and are mostly conducted by statistical authorities in each country. The transferred analysis relates to the period between 2005 and 2011. In 2005, an investigation began in the Czech Republic and 2011 was the last year for which data was available at the time this thesis was written.

Using the household as the basic unit of investigation means that the relationships among the members of family are not important for the scope of this study. Table 1 presents the minimum effective sample size in the EU-SILC survey.

TABLE I. MINIMUM EFFECTIVE SAMPLE SIZE IN THE EU-SILC SURVEY

\begin{tabular}{|c|c|}
\hline Country & Sample size \\
\hline $\boldsymbol{C Z}$ & 4750 \\
\hline $\boldsymbol{F I}$ & 4000 \\
\hline $\boldsymbol{F R}$ & 6500 \\
\hline $\boldsymbol{E} \boldsymbol{S}$ & 7250 \\
\hline $\boldsymbol{U K}$ & 7500 \\
\hline
\end{tabular}

The basic variable is the monthly disposable income per equivalent member. Individual household members are assigned different coefficients. The head of the household has the assessed value of 1 , children under age 130.3 and other members of the household have a coefficient of 0.5 [8]. What matters most here is the head of household. Head of household, according to the Czech Statistical Office [9], in a complete family means husband or partner, a parent in incomplete twogeneration families and a member of the middle generation in three-generation families. In households with more members of non-family type it is considered a person who has been determined as the head of the household.

For comparison, data is expressed in units of the entire work covered by the euro purchasing power standard (PPS).

The analysis is conducted on the income of vulnerable households whose incomes are below the poverty threshold, which is calculated according to the Eurostat definition as $60 \%$ of median equivalised income. It is essential to identify which households are most vulnerable to poverty. The Poverty Risk Index (PRI) serves this purpose, and is calculated by dividing the percentage of poor households in a particular group by the percentage of that group in the population [10].

For better adjudication of poverty, there is the coefficient of the depth of poverty that Proctor and Dalaker defined as the ratio of the average household income to the poverty line [11]. For the calculation, it is necessary to know the poverty line (A) and the average income of households living below the poverty line (a). The indicator of the depth of poverty, which in relative terms is known as the Sen coefficient, is obtained using the formula:

$$
\text { Sen coefficient }=\frac{A-a}{A}
$$
[12].

The closer the value is to 1 , the more intense the poverty In this paper we use comparative approaches of descriptive statistics. The paper also applies regression analysis to determine the dependency between the poverty rate (dependent variable) and other chosen indicators (independent variable). The F-test at the significance level of $\alpha=0.05$ has been used to determine the regression function type suitability.

\section{RESULTS}

A traditional way of expressing the standard of living of a certain country is by its gross domestic product (GDP), which is calculated per capita. GDP is made up of personal consumption, investment, government spending and net exports. Average GDP per capita in the EU in 2011 amounted to 25,600 PPS. The lowest among the selected countries was in the Czech Republic with a value of 10100 PPS, while the highest was in Finland, standing at 29,100 PPS.

Percentage of GDP per capita in PPS to the EU average shows that among the selected countries in 2011, Finland's GDP was $15 \%$ higher than the average among EU states. The standard of living in Spain is closest to the EU average, representing 13th place. Czech Republic PPS was calculated to be $20 \%$ below the average.

TABLE II. GDP PER CAPITA.

\begin{tabular}{|c|c|c|c|c|c|c|c|}
\hline \multirow{2}{*}{ Country } & \multicolumn{7}{|c|}{ GDP per capita, EU = 100 } \\
\cline { 2 - 8 } & 2005 & 2006 & 2007 & $\mathbf{2 0 0 8}$ & $\mathbf{2 0 0 9}$ & $\mathbf{2 0 1 0}$ & $\mathbf{2 0 1 1}$ \\
\hline $\boldsymbol{C Z}$ & 79 & 80 & 83 & 81 & 82 & 80 & 80 \\
\hline $\boldsymbol{F I}$ & 114 & 114 & 118 & 119 & 115 & 115 & 115 \\
\hline $\boldsymbol{F R}$ & 110 & 108 & 108 & 107 & 108 & 108 & 109 \\
\hline $\boldsymbol{E S}$ & 102 & 105 & 105 & 104 & 103 & 100 & 99 \\
\hline $\boldsymbol{U K}$ & 122 & 120 & 116 & 112 & 111 & 112 & 109 \\
\hline
\end{tabular}

In the area of social policy the increased attention is paid to households that are considered poor. Various ways to help them overcome their situation are currently being explored. The issue of poverty is addressed by various organizations around the world. Otherwise it is not in the EU. It is essential to point out that the households most at risk of poverty are most at risk of social exclusion. These household have a disposable income per equivalent member that is less than $60 \%$ of the median. Table 3 below presents the monthly poverty threshold, expressed in PPS, the percentage of households at risk of poverty and the average income of these households in the individual member countries, also in PPS.

During the entire period, the Czech Republic maintained its position among the investigated countries of having the lowest poverty rate where the rate gradually decreased from $10.4 \%$ in 2005 to $8.6 \%$ in 2009 and subsequently increased. In 2011 it was about $9.8 \%$. This is similar to the situation in France, 
where 2005 to 2009 saw a gradual decline in the poverty rate (from $13 \%$ to $12.7 \%$ ), followed by a slight increase in 2010 $(13.4 \%)$ and $2011(14 \%)$.

TABLE III. HOUSEHOLD INCOMES AT RISK FROM 2005 - 2011

\begin{tabular}{|c|c|c|c|c|c|c|c|c|}
\hline Country & Characteristics & 2005 & 2006 & 2007 & 2008 & 2009 & 2010 & 2011 \\
\hline \multirow{3}{*}{$C Z$} & $\begin{array}{l}\text { Monthly poverty } \\
\text { threshold (in PPS) }\end{array}$ & 382 & 413 & 442 & 486 & 505 & 483 & 496 \\
\hline & $\begin{array}{l}\text { Households at risk } \\
\text { of poverty (in \%) }\end{array}$ & 10.4 & 9.9 & 9.6 & 9.0 & 8.6 & 9.0 & 9.8 \\
\hline & $\begin{array}{l}\text { Average income of } \\
\text { households at risk } \\
\text { of poverty (in PPS) }\end{array}$ & 293 & 326 & 343 & 375 & 386 & 364 & 408 \\
\hline \multirow{3}{*}{$F I$} & $\begin{array}{l}\text { Monthly poverty } \\
\text { threshold (in PPS) }\end{array}$ & 707 & 742 & 762 & 828 & 864 & 851 & 883 \\
\hline & $\begin{array}{l}\text { Households at risk } \\
\text { of poverty (in \%) }\end{array}$ & 11.7 & 12.6 & 13.0 & 13.6 & 13.8 & 13.1 & 13.7 \\
\hline & $\begin{array}{l}\text { Average income of } \\
\text { households at risk } \\
\text { of poverty (in PPS) }\end{array}$ & 568 & 598 & 613 & 662 & 689 & 688 & 767 \\
\hline \multirow{3}{*}{$F R$} & $\begin{array}{l}\text { Monthly poverty } \\
\text { threshold (in PPS) }\end{array}$ & 725 & 750 & 758 & 879 & 884 & 878 & 902 \\
\hline & $\begin{array}{c}\text { Households at risk } \\
\text { of poverty (in \%) }\end{array}$ & 13.0 & 13.0 & 13.1 & 12.7 & 12.7 & 13.4 & 14.0 \\
\hline & $\begin{array}{l}\text { Average income of } \\
\text { households at risk } \\
\text { of poverty (in PPS) }\end{array}$ & 563 & 573 & 578 & 669 & 683 & 667 & 749 \\
\hline \multirow{3}{*}{$E S$} & $\begin{array}{l}\text { Monthly poverty } \\
\text { threshold (in PPS) }\end{array}$ & 581 & 628 & 656 & 697 & 699 & 666 & 645 \\
\hline & $\begin{array}{l}\text { Households at risk } \\
\text { of poverty (in \%) }\end{array}$ & 19.8 & 20.0 & 19.7 & 19.7 & 19.5 & 20.7 & 21.8 \\
\hline & $\begin{array}{l}\text { Average income of } \\
\text { households at risk } \\
\text { of poverty (in PPS) }\end{array}$ & 398 & 429 & 451 & 456 & 414 & 376 & 447 \\
\hline \multirow{3}{*}{$U K$} & $\begin{array}{l}\text { Monthly poverty } \\
\text { threshold (in PPS) }\end{array}$ & 845 & 877 & 939 & 919 & 854 & 853 & 840 \\
\hline & $\begin{array}{l}\text { Households at risk } \\
\text { of poverty (in \%) }\end{array}$ & 18.8 & 19.0 & 18.7 & 19.1 & 17.3 & 17.1 & 16.2 \\
\hline & $\begin{array}{l}\text { Average income of } \\
\text { households at risk } \\
\text { of poverty (in PPS) }\end{array}$ & 599 & 622 & 675 & 671 & 617 & 610 & 661 \\
\hline
\end{tabular}

The opposite trend can be observed in Finland, where the percentage of households at risk of poverty since 2005, gradually increased from $11.7 \%$ to $13.8 \%$ in 2009 and then decreased the following year by $0.7 \%$. The highest percentage of households at risk of poverty during the period was in Spain, where there was an increase from $19.8 \%$ in 2005 to $21.8 \%$ in 2011. The UK is the state with the second highest poverty rate in 2005 , which, however, fell from $18.8 \%$ to $16.2 \%$ in 2011.Given the fact that the total percentage of households at risk of poverty in the EU in 2011 was at $16.9 \%$, it can be said that within those countries, Spain is a country with a higher than average number of poor households. Conversely, Czech Republic is the country with the lowest number of income vulnerable households across the EU.

Below is a transferred analysis of the income of vulnerable households by economic activity. Economic activity has a significant impact on household incomes and thus their potential for income risk. For the employed, the unemployed, pensioners and others, various risks exist that they will fall into the groups at risk of poverty. Pensioners and the unemployed are especially susceptible to this, making them important groups to consider in many government decisions. It is therefore necessary to monitor how economic activity is reflected in the income vulnerability of households.

In all of the selected countries, it stands as a rule that the group most at-risk for poverty is the unemployed, while the least threatened group is the employed. Table 4 shows the percentage of the risk of poverty in different social groups in each state. In the Czech Republic, there was a decrease of unemployed people at risk of poverty from $51.4 \%$ in 2005 to $46.5 \%$ in 2011 . A similar decrease also took place in the UK (from $53.6 \%$ to $46.9 \%$ ).

Looking at the Poverty Risk Index (PRI), it can be argued that Finland and the Czech Republic are the countries where the lowest number of poor people is employed.

TABLE IV. HOUSEHOLD INCOMES THREATENED BY ECONOMIC ACTIVITY

\begin{tabular}{|c|c|c|c|c|c|}
\hline \multirow[b]{2}{*}{ State } & \multirow[b]{2}{*}{$\begin{array}{c}\text { Economic } \\
\text { Activity }\end{array}$} & \multicolumn{2}{|c|}{2005} & \multicolumn{2}{|c|}{2011} \\
\hline & & $\begin{array}{c}\text { Relative } \\
\text { number of } \\
\text { households } \\
\text { at risk in \% }\end{array}$ & PRI & $\begin{array}{c}\text { Relative } \\
\text { number of } \\
\text { households } \\
\text { at risk in \% }\end{array}$ & PRI \\
\hline \multirow{4}{*}{$C Z$} & Employed & 3.50 & 0.06 & 4.00 & 0.07 \\
\hline & Unemployed & 51.40 & 7.98 & 46.50 & 7.81 \\
\hline & Pensioners & 6.10 & 0.22 & 6.70 & 0.27 \\
\hline & Other & 16.00 & 1.63 & 14.90 & 0.83 \\
\hline \multirow{4}{*}{$F I$} & Employed & 3.70 & 0.07 & 3.90 & 0.07 \\
\hline & Unemployed & 35.70 & 5.59 & 43.40 & 7.55 \\
\hline & Pensioners & 17.00 & 0.60 & 17.50 & 0.67 \\
\hline & Other & 23.40 & 2.43 & 25.90 & 1.95 \\
\hline \multirow{4}{*}{$F R$} & Employed & 6.10 & 0.12 & 7.60 & 0.13 \\
\hline & Unemployed & 29.40 & 4.97 & 36.70 & 5.58 \\
\hline & Pensioners & 13.40 & 0.51 & 8.30 & 0.27 \\
\hline & Other & 24.90 & 1.78 & 26.40 & 2.05 \\
\hline \multirow{4}{*}{$E S$} & Employed & 10.40 & 0.20 & 12.30 & 0.25 \\
\hline & Unemployed & 34.70 & 4.73 & 40.50 & 3.42 \\
\hline & Pensioners & 24.50 & 1.60 & 25.90 & 1.12 \\
\hline & Other & 27.70 & 1.09 & 29.70 & 1.17 \\
\hline \multirow{4}{*}{$U K$} & Employed & 8.30 & 0.14 & 7.90 & 0.12 \\
\hline & Unemployed & 53.60 & 30.22 & 46.90 & 16.34 \\
\hline & Pensioners & 25.80 & 1.12 & 23.10 & 0.98 \\
\hline & Other & 33.70 & 2.21 & 27.70 & 2.03 \\
\hline
\end{tabular}

In Spain in 2011, 12.3\% of employed people were at risk of poverty, an increase from 2005 of $1.9 \%$. Interestingly, in 2011 in Finland, $17.5 \%$ of pensioners fell below the poverty line, and in the UK this figure was $23.1 \%$, representing a decline. An even larger decline was seen in the incomes of pensioners in France, from $13.4 \%$ to $8.3 \%$. The greatest risk of poverty during the two years was to the unemployed in the UK, although there was a decrease in the PRI from 30.22 to 16.34 .

The depth of poverty is an important indicator by which one can specify how much funding is needed remove a household from the poverty zone. This is therefore expressed as revenue deficit households, which is determined as the difference between a defined poverty line (A) and middle-income households that are below this threshold (a). Certainly it is essential to deal with households in which poverty is deeper and consequently those which are only marginally above the poverty line and therefore require less support. The deeper poverty is, the more relevant it is to society. Calculations of the depth of poverty in the different countries between 2005 and 2011 are given in Table 4. The last column is the Sen 
coefficient, which indicates the relative expression of the depth of poverty.

TABLE V. POVERTY DEPTH

\begin{tabular}{|c|c|c|c|c|c|}
\hline \multirow{2}{*}{ State } & Year & $\boldsymbol{A}($ in PPS) & $\boldsymbol{a}$ (in PPS) & $\begin{array}{c}\boldsymbol{A} \text { - } \boldsymbol{a} \text { (in } \\
\boldsymbol{P P S})\end{array}$ & $\begin{array}{c}\text { Sen } \\
\text { coefficient }\end{array}$ \\
\hline \multirow{2}{*}{$\boldsymbol{C Z}$} & 2005 & 382 & 293 & 89 & 0.23 \\
\cline { 2 - 6 } & 2011 & 496 & 408 & 88 & 0.18 \\
\hline \multirow{2}{*}{$\boldsymbol{F I}$} & 2005 & 707 & 568 & 139 & 0.20 \\
\cline { 2 - 6 } & 2011 & 883 & 767 & 116 & 0.13 \\
\hline \multirow{2}{*}{$\boldsymbol{F R}$} & 2005 & 725 & 563 & 162 & 0.22 \\
\cline { 2 - 6 } & 2011 & 902 & 749 & 153 & 0.17 \\
\hline \multirow{2}{*}{$\boldsymbol{E S}$} & 2005 & 581 & 398 & 183 & 0.31 \\
\cline { 2 - 6 } & 2011 & 645 & 447 & 198 & 0.31 \\
\hline \multirow{2}{*}{$\boldsymbol{U K}$} & 2005 & 845 & 599 & 246 & 0.29 \\
\cline { 2 - 6 } & 2011 & 840 & 661 & 179 & 0.21 \\
\hline
\end{tabular}

In all countries except Spain, in 2011 compared to 2005 we detect a decrease in the average amount of support necessary to remove a household situated below the poverty line from threat. As for Spain, in 2005183 PPS was enough financial support for a household, in 2011 it was $8.1 \%$ more.

Since the Sencoefficients for all of the states are closer to the value 0 rather than 1 , it is possible to say that the poverty rate is average. The highest coefficient values were reached in 2005 and again in 2011 for Spain, at the level of 0.31. Low depth of poverty in Finland, where the coefficient after two years of maintaining the value of 0.20 in 2005 and 0.13 in 2011

Another factor that is highly associated with poverty is income inequality. This inequality can be measured by various indicators, including the S80/S20 ratio, which indicates how many times the incomes of households are in the top quintile compared to the income of households in the bottom quintile. The coefficient S80/20 confirms that Spain and the United Kingdom are the countries with the highest inequality of income. In Spain in 2011, the income of a household in the top quintile was 6.8 times higher than that of a household in the bottom quintile.

TABLE VI. COEFFICIENT S80/S20

\begin{tabular}{|c|c|c|}
\hline \multirow{2}{*}{ Country } & \multicolumn{2}{|c|}{ Coefficient S80/S20 } \\
\cline { 2 - 3 } & $\mathbf{2 0 0 5}$ & $\mathbf{2 0 1 1}$ \\
\hline $\boldsymbol{F I}$ & 3.7 & 3.5 \\
\hline $\boldsymbol{F I}$ & 3.6 & 3.7 \\
\hline $\boldsymbol{E S}$ & 4.0 & 4.6 \\
\hline $\boldsymbol{U K}$ & 5.5 & 6.8 \\
\hline
\end{tabular}

Simple regression, which examines the impact of poverty on S80/S20 indicator, separately identified highly significances addictions. S80/S20 quintile ratio has $85 \%$ ability to explain poverty. Increases in income inequality, measured by the coefficient of S80/S20 by one unit are connected with a more than $3 \%$ increase in the number of vulnerable incomes of households.

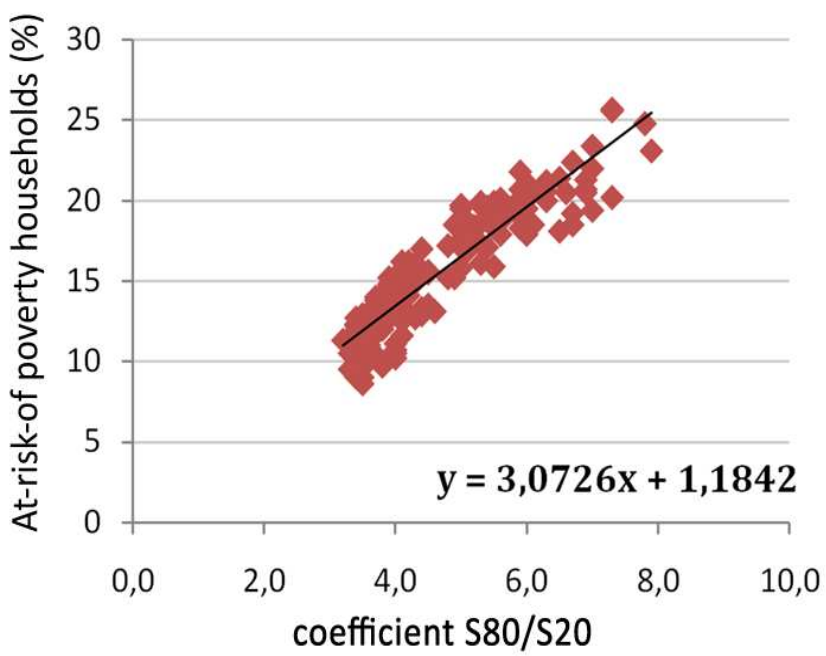

$$
\begin{aligned}
& \text { Number of cases: } 160 \quad R=0,9215 \\
& P=0,000004 \quad F=22,9816
\end{aligned}
$$

FIGURE 1.

REGRESSION ANALYSIS (S80/S20 VS. PERCENTAGE OF POVERTY)

\section{CONCLUSION}

Between 2005 and 2009, the low risk of poverty rate of households across the EU and in the Czech Republic, declined from $10.4 \%$ to $8.6 \%$ and then increased to $9.8 \%$ in 2011 . In 2011, 14\% of French households were poor. From 2005 to 2009, the percentage of household in Finland below the poverty line grew, until it dropped to $13.1 \%$ in 2010 and then rose again to $13.7 \%$ in 2011 . Spain exhibited a higher number of at-risk households (16.9\%) in 2011 than the European average $(21.8 \%)$. The United Kingdom recorded values slightly lower (16.2\%) than those of Spain.

The Poverty Risk Index was used to observe the phenomenon showing that households are most at risk of poverty. Its use is essential due to the fact that it is not possible to compare the poverty of household groups only on the basis of percentages indicating how many of them are poor, because each group has a different household size in the overall population. Index level of risk includes the ratio of the percentage of poor households within the group to the representation of this group among all the inhabitants of the state. Upon investigating income risk on the basis of economic activity it was seen there was a decline in threat to retirees in France, Spain and the UK, which is related to their rising incomes. The population most at risk of poverty is the unemployed British. In 2005, the poverty risk index was 30.2, which despite its downturn to 16.34 still represents the greatest threat to this social group among all states. This situation is due to the fact that the UK, in comparison with other countries, provides the lowest amount of social benefits to the unemployed, accounting for only $3 \%$ of total social transfers.

In addition to poverty rate, it is also necessary to address its depth, as this is a very fundamental component to assessing how much monetary support a household requires to get it out of the poverty zone. In this way it is also possible to evaluate 
social policy. Of course, the behavior of poor consumers will be different from the others, we can expect different preferences, but it also matters how deep below the poverty line their disposable income is located. Based on the calculation of the Sen coefficient, the poverty in Finland is the least deep, with a coefficient value of 0.20 in 2005 and 0.13 in 2011. In the Czech Republic, although there is the least risk of poverty to households, the depth of poverty is greater than in Finland, and in 2010 it was the same as in France. Spanish households, which proved to be the poorest of the selected countries, also suffer from the deepest poverty, as they exhibited the highest Sen coefficient (0.31) in both the first and last reporting years.

Recessions typically affect the most vulnerable populations, so it is therefore essential that the correct social policy of each country be established. Since certain freedoms exist in the EU regarding this approach, each state has to establish its conditions individually, depending on the cultural development of the country. However, it is very difficult to design them so that the system is not abused, and social benefits are attributed to those who really need them and at the same time do not bring about an apathy to work. Factors that influence the formation and deepening of poverty are different. A very strong influence on the evolution of poverty in the EU is income inequality. In countries with high income inequality one can generally find varied hierarchies of classes, prominent levels of class identity and of course a high rate of poverty. Spain is an example of this. It is therefore imperative to focus on reducing income disparities between social groups, broadening and strengthening the middle class in society, thereby reducing poverty.

Special attention should be paid to the situation in Spain, where the economy suffers from a high number of income vulnerable households and high income inequality. The opposite is the case of the Czech Republic. While the UK and Spain stand as two of countries in which the prevalence of these two influential factors are above the European average, Czech Republic, Finland and France are examples of countries in which this prevalence is below the European average. Finland and France are approximately the same in terms of the number of at-risk households. The only difference between them is that France has greater income inequality.

The findings suggest that the problems of poverty, which are associated with the risk of social exclusion, are very serious and also afflict more-developed EU countries. Social policy is a very powerful tool which can greatly reduce poverty. What is important is not only how much money is allocated toward social protection, but also around which social group it is oriented. Improper implementation of social policy causes hindrances to economic activity, slowing economic growth and thus reducing the standard of living of citizens. Since social policy plays such an important role in this process, it is imperative that it be used effectively by each and every country. It is favorable to focus more on training at-risk groups and job creation.

\section{REFERENCES}

[1] F. Bourguignon, S. R. Chajravarty. "The Measurement of Multidimensional Poverty". Journal of Economic Inequality. 2003, vol. 1, no. 1 , p. 25 - 49. ISSN 1569-1721.

[2] R. Lister. Poverty. Cambridge: Polity Press, 2004. 238 s. ISBN 0-74562564-9.

[3] R. Stojanov, M. Jamborová, L. Dušková.K. Kavanová. Development Assistance in the light of practice. Olomouc: Palacký University. 2008. ISBN 978-80-244-2017.

[4] European Anti-Poverty Network, 2008. http://www.eapn.eu/en/newsand-publications/news/intro/blog

[5] J. Broadshaw. N. Finch. Overlaps in dimensions of poverty. Journal of Social Policy. 2003, vol. 32, no. 4, p. 513 - 525. ISSN 0047-2794.

[6] K. Caminada. K. Goudswaard, F. Koster. Social income transfers and poverty alleviation in OECD countries. Leiden University, Department of Economics Research Memorandum. [online]. File of format PDF. 2010. [cit. 2012-03-05]. Received from: <http://papers.ssrn.com>.

[7] J. Světlík.Marketing pro evropský trh. Praha: Grada, 2003. 272 s. ISBN 80-247-0422-6.

[8] E. N. Wolff. Poverty and Income Distribution. Oxford: WileyBlackwell, 2009.650 p. ISBN 978-1-4051-7660-6.

[9] Czech Statistical Office, 2012.

[10] T. Sirovatka. P. Kofron̆. R. Jahoda. Rizika prijmove chudoby a materialni deprivace $\mathrm{v}$ Česke republice (celkova situace a vybrane aspekty na datech SILC). (Risks of Income Poverty and Material Deprivation in the Czech Republic - an Overall Situation and Selected Aspects Based on the SILC Data.) 2011. VUPSV,v.v.i., Prague; ISBN 978-80-7416-092-9.

[11] J. Turčinková. J. Stavková.Assessment of the income situation of households in the Czech Republic. 2011. Agricultural Economics Czech, 57: 322-330.

[12] L. Kabat L.Prijmova situacia a životne podmínky obyvatel'stva Slovenska podl'a štatistiky SILC. (The Slovak population's income situation and living conditions.) 2007. Slovenska štatistika a demografia, 17: 3-21. 